\title{
Developing a deeper insight into reproductive biomarkers
}

\author{
Braira Wahid ${ }^{1,2}$, Hamid Bashir ${ }^{1}$, Muhammad Bilal', Khansa Wahid ${ }^{3}$, Aleena Sumrin ${ }^{1}$ \\ ${ }^{1}$ Centre for Applied Molecular Biology, University of the Punjab, Lahore; ${ }^{2}$ Genome Centre for Molecular Based Diagnosis and Research, Lahore; ${ }^{3}$ Lahore \\ College for Women University, Lahore, Pakistan
}

The development of biomarkers of reproductive medicine is still in its infancy because many black boxes are still present in reproductive medicine. Novel approaches to human infertility diagnostics and treatment must be developed because reproductive medicine has lagged behind in the implementation of biomarkers in clinical medicine. Despite the dearth of the available literature, the current rapid pace of publications suggests that this gap will soon be filled therefore; this review is a précis of the research that has been done so far and will provide a basis for the development of biomarkers in reproductive medicine.

Keywords: Biomarkers; Diagnostics; Infertility; Medicine; Reproduction

\section{Introduction}

Any biological index with the potential to be measured that indicates a defined biological endpoint, such as a disease or developmental stage, is known as a biomarker. Biomarkers may include a wide range of measurable, significant targets, including cellular, biochemical, immunological, genetic, physiological, and molecular changes. Biomarkers help us acquire knowledge about the effects and nature of an exposure and the vulnerability of organisms towards the noxious impacts of that exposure.

Large-scale research has been conducted into the development of biomarkers to predict patients' responses to drugs and to diagnose clinical conditions, extending to all therapeutic areas, including reproductive medicine. Biomarkers can be used to identify subgroups for whom treatment is likely to be successful, to improve the assess-

Received: Mar 1, 2017 · Revised: Oct 26, 2017 · Accepted: Nov 20, 2017

Corresponding author: Hamid Bashir

Centre for Applied Molecular Biology, University of the Punjab, 87-West Canal

Bank Road, Lahore-53700, Pakistan

Tel: +92-42-5293141 Fax:+92-42-5293149 E-mail: hamid.camb@pu.edu.pk

This is an Open Access article distributed under the terms of the Creative Commons Attribution Non-Commercial License (http://creativecommons.org/licenses/by-nc/4.0/) which permits unrestricted non-commercial use, distribution, and reproduction in any medium, provided the original work is properly cited.
onrestrialed non- ment of exposures, and to predict the results, consequences, and classification of subgroups of potentially diverse disease etiologies [1]. It has been reported that 1.5 million women are infertile [2]; likewise, another study documented a prevalence of infertility of $9 \%$ among males [3].

Biomarkers can serve as a measurable indicator of proliferation and differentiation indices [4], the formation of DNA adducts or damage [5], apoptotic endpoints [6], chromosomal abnormalities [7], measurements of enzyme activity [8], micronucleus formation [9], changes in gene expression profiles [10], the expression of specific genes [11], and the presence of a parent compound or metabolite [12].

Biomarkers associated with reproductive impairment are principal early-warning signals of ecosystem impacts, and they require complete validation and characterization in an ecosystem [13]. Potential biomarkers of reproductive impairment are in various stages of development.

Biomarkers serve several distinct purposes in reproductive medicine, including: (1) biomarkers of a disease or developmental stage: some biomarkers serve as indicators of specific phases in normal and abnormal developmental processes; (2) biomarkers of effect: physical or chemical environmental exposures can generate an assembly of localized or systemic effects and can be measured at the molecu- 
lar, cellular, or clinical level; (3) biomarkers of exposure: biomarkers can be used to identify potential toxic exposures because of significant changes in biological function or appearance that signify exposure to a specific stimulus of a biological, physical, or chemical nature; (4) biomarkers of susceptibility: genetic biomarkers may also be used to identify predisposition to develop specific conditions [14].

Improving exposure assessments refers to differentiating subfertile patients from infertile patients and identifying the severity and extent of subfertility. A marker can also identify when a couple is best served by in vitro fertilization. Monitoring susceptibility to the effects of treatment and identifying subgroups may help individualize treatment of patients who are in dire need of a higher dose of medication or alteration of standard laboratory conditions such as oxygen tension or media. The accuracy of the prognosis may be improved by early detection of the number of embryos or which embryo is to be used in in vitro fertilization and the prediction of abortion, obstetric complications (preterm labor or preeclampsia), and ectopic pregnancy. The classification of patients into subtypes with different etiologies helps differentiate between implantation failure and unexplained infertility.

Most reproductive biomarkers that have been developed so far deal with diagnostics, such as the diagnosis of polycystic ovarian disease, endometriosis, infertility, and the viability and location of early pregnancy. Multivariate biomarkers have also been developed; for example, the first diagnostic test based on a multivariate biomarker was OVA1, developed by Vermillion intended to be used for debulking surgery of patients suffering from ovarian adnexal masses. Recently, another multivariate biomarker to diagnose endometriosis has also been developed. To date, about 20 biomarkers have been identified in the serum for the early diagnosis of ectopic pregnancy [15]. Biomarkers approved by the Food and Drug Administration are shown in Table 1.

\section{Neohormones as reproductive biomarkers}

Neohormones are new paracrine or endocrine adaptations that have the ability to define mammalian success to complement physiological functions. Relaxin like peptide hormones are common neohormones, as they define basic reproductive physiology, such as viviparity with placentation or implantation, lactation, and adaptations required by sperm cells for successful internal fertilization, thereby acting as highly useful biomarkers to characterize and monitor reproductive diseases. $\mathrm{H} 2$-relaxin assists in implantation and the development of the placenta in the ovary, whereas its levels change in cases of early miscarriage. During fetal development, testicular INSL3 is important for the first phase of testicular descent, but it may be disrupted in cryptorchidism. In adults, INSL3 is considered to be an antiapoptotic factor in follicle selection (female) and germ cell survival (male), and serves as an excellent indicator of Leydig cell functional capacity, especially in aging males. Likewise, INSL5 and INSL6 have been reported to be involved in the maintenance of adequate spermatogenesis [16].

\section{Endocannabinoids as potential biomarkers in reproductive medicine}

Endocannabinoids and anandamide have proven to be potential biomarkers of reproductive impairments. These are a group of bioactive lipids that act as crucial signals in human reproduction. Fluctuations in the balance between the degradation or decay and synthesis of endocannabinoids lead to local changes in the human male and female reproductive tracts, which in turn adjust and control several pathophysiological processes, including sperm and oocyte maturation [17]. A study revealed that endocannabinoids measured in the saliva could be used as a biomarker of obesity [18].

Table 1. FDA-approved biomarkers [1]

\begin{tabular}{|c|c|c|c|}
\hline Therapeutic area & $\begin{array}{l}\text { No. of tested } \\
\text { biomarkers }\end{array}$ & Intended use & Example \\
\hline $\begin{array}{l}\text { Reproductive } \\
\text { endocrinology }\end{array}$ & 3 & $\begin{array}{l}\text { Identify hepatic CP450 polymorphisms to avoid metabolic } \\
\text { safety risks }\end{array}$ & Tolterodine: level of hepatic CYP2D6 expression \\
\hline Psychiatry & 30 & $\begin{array}{l}\text { Identify hepatic CP450 polymorphisms to avoid drug-drug } \\
\text { interactions }\end{array}$ & $\begin{array}{l}\text { Risperidone: CYP2D6 polymorphisms associated with listed } \\
\text { drug interactions and clinical pharmacology }\end{array}$ \\
\hline Oncology & 10 & $\begin{array}{l}\text { Reduce exposure of drugs in patients with a hepatic CP450 } \\
\text { polymorphism at risk for an adverse response }\end{array}$ & Irinotecan: UGT1A1*28 allele \\
\hline $\begin{array}{l}\text { Oncology, } \\
\text { stratification }\end{array}$ & 14 & Confirm the presence of a mutation before initiating therapy & $\begin{array}{l}\text { Herceptin: HER-2/Neu antibody for c-erbb- } 2 \text { antigen } \\
\text { Cetuximab: therapy recommended for patients without } \\
\text { KRAS mutation }\end{array}$ \\
\hline
\end{tabular}

FDA, Food and Drug Administration; CP450, cytochrome P450; IL, interleukin. 


\section{Biomarkers of common reproductive impairments in males}

About $5 \%-20 \%$ of males suffer from infertility because of obstructive azoospermia, non-obstructive azoospermia, and pretesticular azoospermia. A study found that several proteins expressed in the epididymis and testis were directly associated with fertility. The concentration of seminal plasma proteins such as TEX101 and ECM1 can be used as biomarkers for diagnosing azoospermia [19]. The down regulation of several genes, such as SPATA3, SPACA4, FAM71F1, UBQLN3, GGN, and AKAP4 has been observed in infertile males. Likewise, the upregulation of TMEM225, ADCY10, WBSCR28, GSG1, FSCN3, GTSF1L, and SPATS1 was identified in males with late maturation arrest. Therefore, a molecular diagnostic tool for determining the degree of spermatogenic impairment could be developed using those genes [20-22]. Another study [23] found that total measurements of serum cathepsin $\mathrm{D}$ and $\mathrm{K}$ activity and total sialic acid can serve as biomarkers for distinguishing between benign prostatic hyperplasia and prostate cancer.

The DNA degradation index has been proven to be a noninvasive biomarker for identifying infertile individuals with varicocele, a condition that causes impaired testicular function and is associated with increased fragmentation in sperm DNA [24]. Seminal plasma can be used in the discovery of biomarkers because the seminal plasma proteome contains a plethora of proteins, including tissue-specific proteins, and may be used to monitor pathological processes [25].

\section{Biomarkers of common reproductive impairments in females}

About $15 \%$ of the female population faces infertility issues because of premature ovarian failure [26]. Anti-Müllerian hormone has been proven to be a sensitive biomarker for detecting the menopausal transition [27]. Another study [28] suggested that low serum antiMüllerian hormone levels are an indication of early ovarian aging. The level of serum miR-21 is elevated in women suffering from polycystic ovary syndrome, so serum miR-21 can act as a biomarker for diagnosis of polycystic ovary syndrome [29]. A study [30] reported that the measurement of adipokine levels in serum is not a good marker for polycystic ovary syndrome, whereas high levels of antiMüllerian hormone and low sex hormone-binding globulin levels indicate polycystic ovary syndrome. Oncofetal protein IMP3 may act as a diagnostic biomarker for the detection of endometrial cancers. An increase in the expression of IMP3 has been observed in the decidualized endometrial stroma of chorionic villi and gestational endometrium during early pregnancy [31]. The hypermethylation of SOX1, HS3ST2, and AJAP1 is an indicator of endometrial cancer in atypical hyperplasia patients. Therefore, these genes can also be used as biomarkers for screening atypical hyperplasia [32].

\section{Biomarkers of an abnormal corpus luteum}

\section{Progesterone}

Progesterone is a pregnancy hormone, and its presence in the blood was confirmed in 1958. Its level rises from less than $0.1 \mu \mathrm{g} / 100$ $\mathrm{mL}$ (nonpregnant) up to $87 \mu \mathrm{g} / 100 \mathrm{~mL}$ during pregnancy [33]. Low progesterone levels have been reported in cases of premature births. Progesterone keeps the uterus quiet during pregnancy, reduces the mother's immune response, and supports the implantation of the fetus in the uterus. A decrease in progesterone levels facilitates the onset of labor and stimulates milk production. Lower progesterone concentrations than normal are the leading cause of premature labor $[34,35]$, and this can be prevented by administering progesterone to pregnant women $[36,37]$.

Serum progesterone has been reported as a potential biomarker for differentiating nonviable pregnancies from viable pregnancies $[38,39]$. The combination of human chorionic gonadotropin with progesterone improves the specificity of monitoring fetal viability during early gestation [38]. Receptors of estrogen and progesterone act as prognostic biomarkers of ovarian cancer [40].

\section{Inhibin}

An ovarian hormone known as inhibin inhibits the secretion of follicle-stimulating hormone. This hormone regulates fertility and declines to a negligible level after menopause. It has been reported that some life-threatening ovarian malignancies, such as granulosa cell tumors and mucinous carcinomas, continue to secrete inhibin into the serum. Therefore, a highly accurate diagnostic test based on serum inhibin levels has been developed for granulosa cell tumors and mucinous carcinomas. Likewise, when the cancer antigen 125 (CA-125) test is used in conjunction with an inhibin assay, epithelial ovarian carcinomas are detected, and both of these tests can also identify a large majority of ovarian cancers with high specificity and sensitivity [41]. It has been reported in the New England Journal of Medicine that the serum concentration of inhibin was elevated in most postmenopausal women with granulosa cell tumors and mucinous carcinomas, but a significant decrease in the concentration was observed after removal of the tumor [42].

Inhibins act as biomarkers of reproductive cancers. In various prostate and gonadal cancers, the concentration of inhibin $A$ and inhibin $B$ is elevated, so they act as diagnostic biomarkers for reproductive cancers and as immunocytochemical markers for the analysis of tissue sections [43]. Another study suggested that human sex cord stromal tumors secrete inhibin $A$ and inhibin $B$, which are potent bio- 
markers of tumors [44].

Sertoli cells produce glycoprotein inhibin $B$, which plays a key role in the regulation of follicle-stimulating hormone by a negative feedback loop. The concentration of systemic inhibin $B$ is an indicator of spermatogenic status because a higher concentration of inhibin $B$ indicates normal fertility, whereas a lower level of inhibin $B$ is observed in men with damaged testes because of germ cell depletion. Therefore, inhibin $B$ has been identified as a potential biomarker for monitoring male infertility; in fact, a study reported that inhibin B combined with follicle-stimulating hormone exhibited a higher positive predictive value than inhibin for detection of male infertility $[45,46]$.

\section{Renin and relaxin}

Relaxin is a hormone that is proteinaceous in nature and is secreted by the corpus luteum during gestation [47]. Its concentration increases soon after conception and remains steady through the 15th week of gestation [48]. A preliminary assessment demonstrated that the levels of relaxin in the serum of individuals with a tubal ectopic pregnancy were considerably lower than in patients with a viable intrauterine pregnancy [49]. It has been proposed that renin may serve as marker of future cardiovascular events [50]. Most patients with a tubal ectopic pregnancy exhibited a low level of relaxin, so relaxin may act as a biomarker of ectopic pregnancy [51]. A study [52] reported reduced rennin levels in women with ectopic pregnancy, in comparison to women with a spontaneous miscarriage or ongoing intrauterine pregnancy.

\section{Biomarkers of the fallopian tube and pregnancy maintenance}

\section{Vascular endothelial growth factor}

Vascular endothelial growth factor (VEGF) is a dominant angiogenic factor important in vascular growth, remodeling, and permeability [53]. It regulates angiogenesis in the endometrium [54] and corpus luteum [55]. VEGF also plays a key role in placentation and implantation. The expression of VEGF is triggered by tissue hypoxia [56]. It was hypothesized that serum VEGF levels would be elevated in tubal ectopic pregnancy, regardless of its role in endometrial and luteal development, and it was found that VEGF levels in the serum were considerably higher in patients with a tubal ectopic pregnancy than in those with a normal intrauterine pregnancy [57]. Serum VEGF levels are usually elevated in patients with disseminated cancer [58]. The concentration of VEGF is elevated in endometriosis patients [59].

In squamous cell carcinoma of the head and neck, measurements of the serum VEGF levels may serve as a biomarker for the prognosis of response to therapy, and a study reported its use as a diagnostic biomarker of major depressive disorder $[60,61]$. In contrast, another study suggested that nerve growth factor beta (NGF- $\beta$ ) and VEGF are principal neurotrophic factors of the male reproductive system. They reported that a decrease in VEGF and NGF- $\beta$ was associated with increased testicular damage and apoptosis in diabetic rats. Testis NGF- $\beta$ and VEGF levels may prove to be effective novel biomarkers of diabetes-induced testicular damage [62].

\section{Creatine kinase}

Creatine kinase is an enzyme released in response to muscle damage, and may also be used as a marker of fallopian tube damage and a biomarker for the diagnosis of myocardial infarction [63]. A study of women with ruptured ectopic pregnancies, unruptured ectopic pregnancies, and normal intrauterine pregnancies found higher concentrations of creatine kinase in the serum of individuals suffering from ruptured tubal ectopic pregnancy than in those with a normal intrauterine pregnancy or unruptured tubal ectopic pregnancy. The concentration of creatine kinase is influenced by tubal location, because it is considerably higher in women with an isthmic pregnancy than in ampullary pregnancies. Moreover, it was recently confirmed that creatine kinase levels multivariate biomarker was OVA1, higher in ruptured ectopic pregnancies and isthmic tubal ectopic pregnancies. Tubal ectopic pregnancy grows and progresses towards a state of causing damage, so the increase in the concentration of serum creatine kinase in the serum is a marker for monitoring whether a pregnancy is normal $[64,65]$.

\section{Biomarkers of abnormal fetal growth}

\section{Pregnancy-specific b-1-glycoprotein (Schwangerschaft protein 1)}

Pregnancy-specific beta glycoprotein or Schwangerschaft protein 1 (SP1) is one of the earliest proteins to be detected in immunohistochemical techniques and trophoblast culture as a biomarker [66] and its function in the diagnosis of ectopic pregnancy has additionally been supported and validated by proteomic discoveries [67]. When serial analyses of SP1 were assessed using an enzyme-linked immunosorbent assay in apparently normal pregnancies and complicated pregnancies, SP1 was found to decrease with increasingly severe retarded intrauterine growth, while it increased with increasingly severe hypertension during pregnancy [68].

\section{Human placental lactogen}

Human placental lactogen (hPL) is secreted by the placenta, and can be monitored during the first trimester of pregnancy. Levels of hPL are lower in pregnant women with tubal ectopic pregnancy than in those with a normal intrauterine pregnancy, especially after 7 weeks of gestation. The placenta synthesizes hPL that is secreted into 
the maternal serum $[69,70]$. hPL serves as diagnostic biomarker to screen for Down syndrome and other impairments during the first trimester of pregnancy [71].

\section{Human chorionic gonadotropin}

Human chorionic gonadotropin (hCG) is the only biomarker currently used routinely in clinical practice $[72,73]$. hCG is released by trophoblasts and an increase in its level indicates the viability and survival of an embryo. It is a heterogeneous glycoprotein, consisting of an alpha and beta subunit that can differ in carbohydrate and peptide structure. Pregnancy can be monitored easily because immediately after conceiving, early trophoblast cells start producing hCG, which acts on corpus luteum cells to promote progesterone production.

Two variants of hCG stimulate invasion, malignancy, and tumor cell growth. Cytotrophoblast cells produce hyperglycosylated hCG, which acts as a tumor marker for gestational trophoblastic diseases and as a biomarker for cytotrophoblast cells $[74,75]$. Interactions between the secretion level of hyperglycosylated hCG and oxidative stress produced by hydrogen peroxide have been demonstrated through in vitro studies of placental function. In a study of the association between hydrogen peroxide and maternal levels of hCG, pregnant women with preeclampsia exhibited a correlation between systemic hCG levels and oxidative stress. Another study [76] demonstrated that circulating hCG could be used as a biomarker or a tool for monitoring oxidative stress during pregnancy.

\section{Pregnancy-associated plasma protein-A}

Pregnancy-associated plasma protein-A (PAPP-A) may act as a biomarker for the prenatal screening of trisomy 21. A study [77] identified the overexpression of PAPP-A in Down syndrome from placental messenger RNA in the mother's serum proteins. Levels of inhibin A and hCG increase in trisomy 21, whereas those of alpha-fetoprotein ( $a-F P)$ and unconjugated estriol decrease [78]. PAPP-A regulates insulin-like growth factor, which is necessary for the development of the fetus. The level of this protein increases throughout gestation, but decreases after pregnancy. Screening of Down syndrome is based on the concentration of PAPP-A measured during the first trimester of pregnancy. Levels of PAPP-A decrease during the second trimester of pregnancy in women who subsequently develop preeclampsia in comparison with those who do not. Conversely, its concentration is elevated even more in individuals with preeclampsia than those without preeclampsia during the last trimester of pregnancy [79].

\section{5. a-Fetoprotein}

a-FP acts as a diagnostic biomarker for monitoring fetal developmental abnormalities, such as Down syndrome or neural tube de- fects, as well as for the development of tumors such as hepatocellular carcinomas. A study of $\alpha$-FP in knock-out mice revealed that $\alpha-F P$ is necessary for female fertility; this relationship was found to be mediated through its estrogen-binding capacity, because the anti-estrogenic action of $\alpha-F P$ controls female fertility [80]. $\alpha-F P$ is produced by the embryo and is secreted into the amniotic fluid. It may cross the placental barrier to enter the mother's blood, in which the titer is measured to diagnose developmental abnormalities of the fetus [81]. Levels of $\alpha-F P$ are measured at 14-22 weeks of pregnancy [82]. An elevated level of $\alpha-F P$ in maternal serum indicates neural tube defects such as anencephaly or spina bifida [83], and lower levels of a-FP signify a risk of Down syndrome in the developing fetus [84]. Antenatal Down syndrome is screened for using a quadruple test of a-FP, inhibin A, hCG, and unconjugated estradiol [82].

\section{Biomarkers of normal implantation}

\section{Progestagen-associated endometrial protein/glycodelin (placental protein-14)}

Progestagen-associated endometrial protein (placental protein-14 [PP-14]) is a glycoprotein (molecular weight: $28 \mathrm{kDa}$ ) with a sequence homologous to $\beta$-lactoglobulins, consisting of a retinolbinding motif. Human serum contains progestagen-associated endometrial protein at nanomolar concentrations. This protein is secreted by the seminal vesicle epithelium in men and produced by decidualized and secretory endometrium in women [85]. PP-14 regulates the uterine environment to make it suitable for pregnancy, and also plays an important role in the occurrence and timing of the suitable sequence of events in the fertilization process [86]. In healthy women, serum PP-14 concentrations begin to increase during the mid-luteal phase and start to decline during the mid-follicular phase of the menstrual cycle, and a significant decrease in the PP-14 level is observed between the mid-follicular and mid-luteal phases of the menstrual cycle [87]. The concentration of progesterone-associated endometrial protein is lower in the endometriosis-affected endometrium than in the normal endometrium [88].

\section{Leukemia inhibitory factor}

Leukemia inhibitory factor belongs to the interleukin- 6 family of cytokines, and it is a key contributor to human reproduction, implantation, and inflammation. It is involved in the regulation of differentiation and growth of embryonic stem cells, peripheral neurons, adipocytes, osteoblasts, endothelial cells, and primordial germ cells [89]. A study [90] revealed that leukemia inhibitory factor was associated with successful pregnancy initiation, so it may serve as a potential biomarker of pregnancy. 


\section{Biomarkers of reproductive cancers}

\section{Follistatin}

Follistatin is a glycoprotein present in the follicular fluid of the ovary. It serves as a biomarker of ovarian mucinous tumors and pregnancy. Another study suggested its use in the diagnosis of lung adenocarcinoma because lung adenocarcinoma cells secrete follistatin into the serum, which can be supportive for the survival of adenocarcinoma cells by neutralizing the action of activin $\mathrm{A}[91,92]$.

\section{Cancer antigen 125}

Ovarian carcinoma is diagnosed by CA-125. It is a tumor-associated antigen released by the coelomic epithelium that serves as a useful biomarker for endometriosis [93]. It is secreted in bodily fluids in soluble form or expressed on cell surfaces that experience metaplastic differentiation into Müllerian-type epithelium. The level of CA-125 is elevated in benign conditions such as uterine fibroids and endometriosis, and its levels also increase during early pregnancy [52,94]; therefore, it is a useful biomarker. Elevated levels of soluble CA-125 have been reported in several other malignant conditions, such as non-Hodgkin lymphoma [95], mesothelioma [96], leiomyosarcoma and leiomyoma of gastrointestinal origin [97], breast cancer [98], gastric cancer [99], liver diseases, ovulatory cycles [100], congestive heart failure [101,102], and tuberculosis [103].

\section{Interleukin-8}

Interleukin-8 is an important contributing factor to male genital tract inflammation/infection. It is associated with benign prostatic hyperplasia-related inflammation. Among several chemokines and cytokines, seminal plasma interleukin-8 may serve as a predictive and reliable surrogate marker of prostatitis and leukocytospermia. It has also been reported that seminal plasma interleukin-8 is involved in the swelling of the prostate, along with other organs of the male reproductive tract, especially the epididymis and seminal vesicles, but not the testis [104]. Interleukin-8 has also been found to be a promising marker for several clinical conditions, such as non-Hodgkin lymphoma, chorioamnionitis, nosocomial bacterial infections, osteomyelitis, inflammatory bowel disease, acute pyelonephritis, pulmonary infections, vesicoureteral reflux, prostatitis, and urinary bladder cancer [105].

\section{Interleukin-6}

Interleukin- 6 is a multifunctional cytokine that acts as a triggering factor of B-lymphocytes because it triggers the differentiation of $B$ cells, which give rise to antibody-producing plasma cells. Interleukin- 6 affects the progression of prostate cancer and prostate carcino$\mathrm{ma}$, as well as the production of prostate-specific antigen [106].
Menstrual effluents contain interleukin- $1 \beta$, interleukin- 6 , and tumor necrosis factor $\alpha$, thereby acting as a biomarker of chronic endometritis [107], and it has been reported that the tumor necrosis factor a gene promoter region is more highly expressed in women with endometriosis [108].

\section{Biomarkers for measuring the estrogenic effects of endocrine disruptors}

Many environmental chemicals act as endocrine disruptors, such as dichlorodiphenyl-trichloroethane, dioxins, and polychlorinated biphenyls, which are anti-androgenic and estrogen-like in nature. They impede natural hormonal action and cause infertility in males. Prostate and testicular cancers, hypospadias, undescended testis, abnormal sexual development, Sertoli cell-only patterns, and altered thyroid and pituitary gland functions have been found to be caused by endocrine disruptors [109].

\section{Complement component 3 and ornithine decarboxylase}

Many genes identified in the uterus have served as marker genes to evaluate the estrogenicity of endocrine disruptors. For example, the plasma glycoprotein clusterin gene, genes responsible for gap junction connexins, such as connexin 26 and connexin 43, and complement component 3 (C3) have been shown to be controlled by the endometrium of rats. $\mathrm{C} 3$ was found to be produced in the uterus of female mice. C 3 is a protein that is an important contributor to immunity. In the uterus, endocrine disruptors increase the expression of the gene for ornithine decarboxylase. Therefore, these genes sensitive to estrogen have served as markers to analyze the estrogenic potential of endocrine disruptors of the uterus [110-112].

\section{Vitellogenin}

A study done on fish has reported that vitellogenin (VTG) is a precursor protein of egg yolk secreted by liver cells and released into the blood, from which it reaches the ovaries and promotes oocyte development; moreover, it has been proposed that VTG can also be used as a potential biomarker for estrogenic chemicals [113]. Although VTG is also present in male fish, it is not normally expressed due to the low circulating level of Estradiol $\left(E_{2}\right)$ in the blood plasma; however, males have been shown to have ability to express VTG under the influence of estrogenic endocrine disruptors; thus, it has been proposed that the VTG gene in male fish may be used as a biomarker for analyzing the effects of endocrine disruptors [114-116].

\section{3. pS2 and mucin 1}

A study revealed that estrogenic compounds and $\mathrm{E}_{2}$ triggered the expression of pS2 in the cloning of the pS2 gene in the MCF- 7 breast 
Table 2. Classification of biomarkers as neohormones, endocannabinoids, and biomarkers of reproductive impairments in males and females

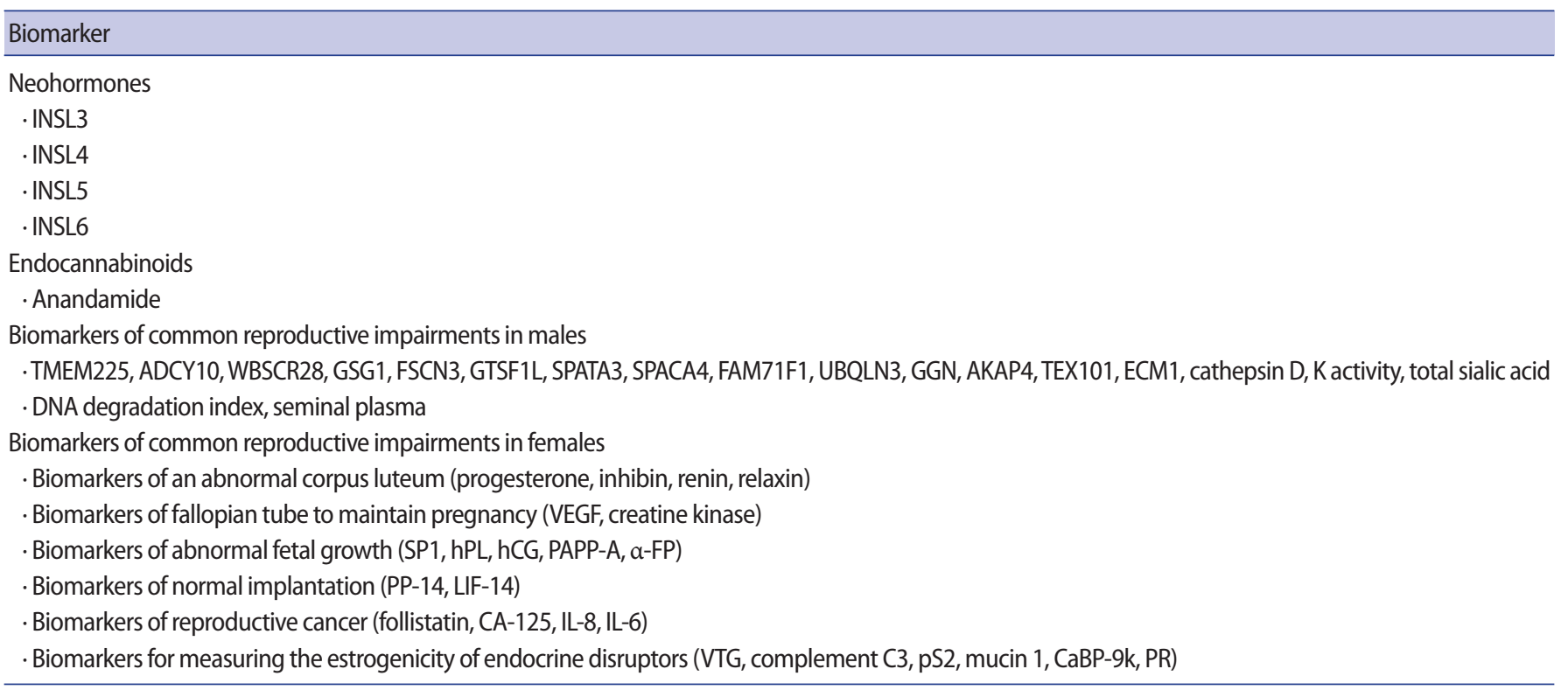

VEGF, vascular endothelial growth factor; SP, Schwangerschaft protein; $\mathrm{hPL}$, human placental lactogen; $\mathrm{hCG}$, human chorionic gonadotropin; PAPP-A, pregnancy-associated plasma protein-A; $\alpha$-FP, alpha-fetoprotein; PP-14, placental protein-14; LIF, leukemia inhibitory factor; CA-125, cancer antigen 125; IL, interleukin; VTG, vitellogenin; C3, component 3; CaBP-9k, calbindin-D9k; PR, progesterone receptor.

cancer cell line [117]. The production of pS2 mRNA can be induced by $\mathrm{E}_{2}$ in some breast cancers, but not in normal breast tissue or in any other human cell lines. Therefore, the expression of pS2 mRNA in MCF-7 cells is an ideal model for estimating the impact of estrogenic compounds [117-119]. Mucin1 is an extended rod-like molecule protruding above the surface of epithelial cells, and it acts as a wellknown marker of breast cancer [120].

\section{Progesterone receptor}

The steroid receptor known as progesterone receptor binds with progesterone, and it is involved in a several physiological functions such as homeostasis, cell differentiation, and the control of embryonic development [121-123]. To evaluate the estrogenicity of endocrine disruptors efficiently in a cost- and time-effective manner, the expression levels of progesterone receptor genes are measured [116].

\section{Calbindin-D9k}

The use of calbindin-D9k (CaBP-9k) as a biomarker for endocrine disruptors has been reported. The injection of estrogenic chemicals such as nonylphenol, bisphenol A, 17 $\beta$-estradiol, and 4-tert-octylphenol in immature mice led to $\mathrm{CaBP}-9 \mathrm{k}$ protein assembly and uterine localization, which were confirmed by western blotting and immunohistochemical staining, respectively. A time- and dose-dependent increment in the CaBP-9k protein was identified in the uterus of immature rats when treated with 4-tert-octylphenol and nonylphenol; thus, the CaBP-9k protein could serve a potent biomarker for evaluating the estrogenicity of putative estrogenic compounds [124].

\section{Conclusion}

It is necessary to develop clinically useful biomarkers to inform therapeutic and regulatory decision-making bodies about candidate drugs and their effects in an attempt to resolve reproductive impairments through the development of new diagnostic methods and medicines based on biomarkers. The number of candidate markers in reproductive medicine is increasing, and it is urgently necessary to comprehend the development pathway from discovery to clinical utility. Extensive testing and modification, along with validation, must be performed before a biomarker is demonstrated to have clinical utility. New partnerships and opportunities exist and should hasten the development of reproductive biomarkers. The classification of biomarkers discussed in this review is presented in Table 2.

\section{Conflict of interest}

No potential conflict of interest relevant to this article was reported.

\section{References}

1. Palmer SS, Barnhart KT. Biomarkers in reproductive medicine: the promise, and can it be fulfilled? Fertil Steril 2013;99:954-62.

2. Centers for Disease Control and Prevention. National Center for 
Health Statistics: 2013 [Internet]. Atlanta: Centers for Disease Control and Prevention; 2016 [cited 2017 Dec 9]. Available from: http://www.cdc.gov/nchs/fastats/infertility.htm.

3. Boivin J, Bunting L, Collins JA, Nygren KG. International estimates of infertility prevalence and treatment-seeking: potential need and demand for infertility medical care. Hum Reprod 2007;22:1506-12.

4. latropoulos MJ, Williams GM. Proliferation markers. Exp Toxicol Pathol 1996;48:175-81.

5. Poirier MC, Weston A. Human DNA adduct measurements: state of the art. Environ Health Perspect 1996;104 Suppl 5:883-93.

6. Samaha HS, Kelloff GJ, Steele V, Rao CV, Reddy BS. Modulation of apoptosis by sulindac, curcumin, phenylethyl-3-methylcaffeate, and 6-phenylhexyl isothiocyanate: apoptotic index as a biomarker in colon cancer chemoprevention and promotion. Cancer Res 1997;57:1301-5.

7. Lucas JN. Chromosome translocations: a biomarker for retrospective biodosimetry. Environ Health Perspect 1997;105 Suppl 6:1433-6.

8. Chen WL, Sheets JJ, Nolan RJ, Mattsson JL. Human red blood cell acetylcholinesterase inhibition as the appropriate and conservative surrogate endpoint for establishing chlorpyrifos reference dose. Regul Toxicol Pharmacol 1999;29:15-22.

9. Schoket B, Poirier MC, Mayer G, Torok G, Kolozsi-Ringelhann A, Bognar $\mathrm{G}$, et al. Biomonitoring of human genotoxicity induced by complex occupational exposures. Mutat Res 1999;445:193203.

10. Thomas RS, Rank DR, Penn SG, Zastrow GM, Hayes KR, Pande K, et al. Identification of toxicologically predictive gene sets using cDNA microarrays. Mol Pharmacol 2001;60:1189-94.

11. Riggins GJ. Using serial analysis of gene expression to identify tumor markers and antigens. Dis Markers 2001;17:41-8.

12. Hecht SS. Human urinary carcinogen metabolites: biomarkers for investigating tobacco and cancer. Carcinogenesis 2002;23: 907-22.

13. Anderson SL. 2001 Progress report: a western center for estuarine indicators research which will develop indicators of wetlands ecosystem health. Santa Barbara: Pacific Estuarine Ecosystem Indicator Research (PEEIR) Consortium; 2004.

14. Rockett JC, Lynch CD, Buck GM. Biomarkers for assessing reproductive development and health. Part 1: pubertal development. Environ Health Perspect 2004;112:105-12.

15. Pedersen JF, Ruge $S$. Serum level of secretory endometrial protein PP-14 in intact ectopic pregnancy. Br J Obstet Gynaecol 1991;98:414.

16. Anand-Ivell R, Dai Y, Ivell R. Neohormones as biomarkers of reproductive health. Fertil Steril 2013;99:1153-60.
17. Rapino C, Battista N, Bari M, Maccarrone M. Endocannabinoids as biomarkers of human reproduction. Hum Reprod Update 2014;20:501-16.

18. Matias I, Gatta-Cherifi B, Tabarin A, Clark S, Leste-Lasserre T, Marsicano $G$, et al. Endocannabinoids measurement in human saliva as potential biomarker of obesity. PLoS One 2012;7:e42399.

19. Drabovich AP, Dimitromanolakis A, Saraon P, Soosaipillai A, Batruch I, Mullen $B$, et al. Differential diagnosis of azoospermia with proteomic biomarkers ECM1 and TEX101 quantified in seminal plasma. Sci Transl Med 2013;5:212ra160.

20. Malcher A, Rozwadowska N, Stokowy T, Kolanowski T, Jedrzejczak P, Zietkowiak W, et al. Potential biomarkers of nonobstructive azoospermia identified in microarray gene expression analysis. Fertil Steril 2013;100:1686-94.e1-7.

21. Specht IO, Toft G, Hougaard KS, Lindh CH, Lenters V, Jonsson BA, et al. Associations between serum phthalates and biomarkers of reproductive function in 589 adult men. Environ Int 2014;66: 146-56.

22. Pan $\mathrm{Y}$, Jing J, Dong $\mathrm{F}$, Yao $\mathrm{Q}$, Zhang W, Zhang $\mathrm{H}$, et al. Association between phthalate metabolites and biomarkers of reproductive function in 1066 Chinese men of reproductive age. J Hazard Mater 2015;300:729-36.

23. El Melegy NT, Aboulella HA, Abul-Fadl AM, Mohamed NA. Potential biomarkers for differentiation of benign prostatic hyperplasia and prostate cancer. Br J Biomed Sci 2010;67:109-12.

24. Esteves SC, Gosalvez J, Lopez-Fernandez C, Nunez-Calonge R, Caballero P, Agarwal A, et al. Diagnostic accuracy of sperm DNA degradation index (DDSi) as a potential noninvasive biomarker to identify men with varicocele-associated infertility. Int Urol Nephrol 2015;47:1471-7.

25. Drabovich AP, Saraon P, Jarvi K, Diamandis EP. Seminal plasma as a diagnostic fluid for male reproductive system disorders. Nat Rev Urol 2014;11:278-88.

26. Vujovic S. Aetiology of premature ovarian failure. Menopause Int 2009;15:72-5.

27. lino K, Tarakida A, Abe K, Taniguchi R, Higuchi T, Takahashi I, et al. Role of antimullerian hormone as a biomarker of the menopausal transition. Menopause 2013;20:218-22.

28. Lin PY, Huang FJ, Kung FT, Chiang HJ, Lin YJ, Lin YC, et al. Evaluation of serum anti-Mullerian hormone as a biomarker of early ovarian aging in young women undergoing IVF/ICSI cycle. Int J Clin Exp Pathol 2014;7:6245-53.

29. Jiang L, Li W, Wu M, Cao S. Ciculating miRNA-21 as a biomarker predicts polycystic ovary syndrome (PCOS) in patients. Clin Lab 2015;61:1009-15.

30. Shen SH, Shen SY, Liou TH, Hsu MI, Chang YC, Cheng CY, et al. Obesity and inflammatory biomarkers in women with polycystic 
ovary syndrome. Eur J Obstet Gynecol Reprod Biol 2015;192:6671.

31. Zheng W, Yi X, Fadare O, Liang SX, Martel M, Schwartz PE, et al. The oncofetal protein IMP3: a novel biomarker for endometrial serous carcinoma. Am J Surg Pathol 2008;32:304-15.

32. Lai HC, Wang YC, Yu MH, Huang RL, Yuan CC, Chen KJ, et al. DNA methylation as a biomarker for the detection of hidden carcinoma in endometrial atypical hyperplasia. Gynecol Oncol 2014;135:552-9.

33. Short RV. Progesterone in blood: I. the chemical determination of progesterone in peripheral blood. J Endocrinol 1958;16:41525.

34. Tamby Raja RL, Anderson AB, Turnbull AC. Endocrine changes in premature labour. Br Med J 1974;4:67-71.

35. TambyRaja RL, Turnbull AC, Ratnam SS. Predictive oestradiol surge of premature labour and its suppression by glucocorticoids. Aust N Z J Obstet Gynaecol 1975;15:191-203.

36. Erny R, Pigne A, Prouvost C, Gamerre M, Malet C, Serment H, et al. The effects of oral administration of progesterone for premature labor. Am J Obstet Gynecol 1986;154:525-9.

37. Meis PJ; Society for Maternal-Fetal Medicine. 17 Hydroxyprogesterone for the prevention of preterm delivery. Obstet Gynecol 2005;105(5 Pt 1):1128-35.

38. Phipps MG, Hogan JW, Peipert JF, Lambert-Messerlian GM, Canick JA, Seifer DB. Progesterone, inhibin, and hCG multiple marker strategy to differentiate viable from nonviable pregnancies. Obstet Gynecol 2000;95:227-31.

39. Meulenberg EP. Salivary progesterone as a biomarker in pregnancy. Biochem Anal Biochem 2015;4:188. https://doi.org/ 10.4172/2161-1009.1000188.

40. Sieh W, Kobel M, Longacre TA, Bowtell DD, deFazio A, Goodman $M T$, et al. Hormone-receptor expression and ovarian cancer survival: an Ovarian Tumor Tissue Analysis consortium study. Lancet Oncol 2013;14:853-62.

41. Robertson DM, Oehler MK. Emerging role of inhibin as a biomarker for ovarian cancer. Womens Health (Lond) 2005;1:51-7.

42. Healy DL, Burger HG, Mamers $P$, Jobling T, Bangah M, Quinn M, et al. Elevated serum inhibin concentrations in postmenopausal women with ovarian tumors. N Engl J Med 1993;329:1539-42.

43. Robertson DM, McNeilage J. Inhibins as biomarkers for reproductive cancers. Semin Reprod Med 2004;22:219-25.

44. Yamashita K, Yamoto M, Shikone T, Minami S, Imai M, Nishimori K, et al. Production of inhibin $A$ and inhibin $B$ in human ovarian sex cord stromal tumors. Am J Obstet Gynecol 1997;177:1450-7.

45. Stewart J, Turner KJ. Inhibin B as a potential biomarker of testicular toxicity. Cancer Biomark 2005;1:75-91.

46. Moffit JS, Her LS, Mineo AM, Knight BL, Phillips JA, Thibodeau
MS. Assessment of inhibin B as a biomarker of testicular injury following administration of carbendazim, cetrorelix, or 1,2-dibromo-3-chloropropane in Wistar han rats. Birth Defects Res B Dev Reprod Toxicol 2013;98:17-28.

47. Weiss G, O'Byrne EM, Steinetz BG. Relaxin: a product of the human corpus luteum of pregnancy. Science 1976;194:948-9.

48. Szlachter BN, Quagliarello J, Jewelewicz R, Osathanondh R, Spellacy WN, Weiss G. Relaxin in normal and pathogenic pregnancies. Obstet Gynecol 1982;59:167-70.

49. Garcia A, Skurnick JH, Goldsmith LT, Emmi A, Weiss G. Human chorionic gonadotropin and relaxin concentrations in early ectopic and normal pregnancies. Obstet Gynecol 1990;75:779-83.

50. Jan Danser AH. Renin and prorenin as biomarkers in hypertension. Curr Opin Nephrol Hypertens 2012;21:508-14.

51. Witt BR, Wolf GC, Wainwright CJ, Johnston PD, Thorneycroft IH. Relaxin, CA-125, progesterone, estradiol, Schwangerschaft protein, and human chorionic gonadotropin as predictors of outcome in threatened and nonthreatened pregnancies. Fertil Steril 1990;53:1029-36.

52. Cartwright J, Duncan WC, Critchley HO, Horne AW. Serum biomarkers of tubal ectopic pregnancy: current candidates and future possibilities. Reproduction 2009;138:9-22.

53. Neufeld G, Cohen T, Gengrinovitch S, Poltorak Z. Vascular endothelial growth factor (VEGF) and its receptors. Faseb J 1999; 13:9-22.

54. Fraser HM, Wilson H, Silvestri A, Morris KD, Wiegand SJ. The role of vascular endothelial growth factor and estradiol in the regulation of endometrial angiogenesis and cell proliferation in the marmoset. Endocrinology 2008;149:4413-20.

55. Fraser HM, Duncan WC. Vascular morphogenesis in the primate ovary. Angiogenesis 2005;8:101-16.

56. Ladoux A, Frelin C. Hypoxia is a strong inducer of vascular endothelial growth factor mRNA expression in the heart. Biochem Biophys Res Commun 1993;195:1005-10.

57. Daniel Y, Geva E, Lerner-Geva L, Eshed-Englender T, Gamzu R, Lessing JB, et al. Levels of vascular endothelial growth factor are elevated in patients with ectopic pregnancy: is this a novel marker? Fertil Steril 1999;72:1013-7.

58. Salven P, Manpaa H, Orpana A, Alitalo K, Joensuu H. Serum vascular endothelial growth factor is often elevated in disseminated cancer. Clin Cancer Res 1997;3:647-51.

59. Vodolazkaia A, Yesilyurt BT, Kyama CM, Bokor A, Schols D, Huskens $D$, et al. Vascular endothelial growth factor pathway in endometriosis: genetic variants and plasma biomarkers. Fertil Steril 2016;105:988-96.

60. Srivastava VK, Gara RK, Rastogi N, Mishra DP, Ahmed MK, Gupta $S$, et al. Serum vascular endothelial growth factor-A (VEGF-A) as 
a biomarker in squamous cell carcinoma of head and neck patients undergoing chemoradiotherapy. Asian Pac J Cancer Prev 2014;15:3261-5.

61. Carvalho AF, Kohler CA, McIntyre RS, Knochel C, Brunoni AR, Thase ME, et al. Peripheral vascular endothelial growth factor as a novel depression biomarker: a meta-analysis. Psychoneuroendocrinology 2015;62:18-26.

62. Sisman AR, Kiray M, Camsari UM, Evren M, Ates M, Baykara B, et al. Potential novel biomarkers for diabetic testicular damage in streptozotocin-induced diabetic rats: nerve growth factor beta and vascular endothelial growth factor. Dis Markers 2014;2014: 108106.

63. Costa TN, Cassaro Strunz CM, Nicolau JC, Gutierrez PS. Comparison of MB fraction of creatine kinase mass and troponin I serum levels with necropsy findings in acute myocardial infarction. Am J Cardiol 2008;101:311-4.

64. Chandra L, Jain A. Maternal serum creatine kinase as a biochemical marker of tubal pregnancy. Int J Gynaecol Obstet 1995;49:21-3.

65. Duncan WC, Sweeting VM, Cawood P, Illingworth PJ. Measurement of creatine kinase activity and diagnosis of ectopic pregnancy. Br J Obstet Gynaecol 1995;102:233-7.

66. Earl U, Wells M, Bulmer JN. Immunohistochemical characterisation of trophoblast antigens and secretory products in ectopic tubal pregnancy. Int J Gynecol Pathol 1986;5:132-42.

67. Beer LA, Tang HY, Sriswasdi S, Barnhart KT, Speicher DW. Systematic discovery of ectopic pregnancy serum biomarkers using 3-D protein profiling coupled with label-free quantitation. J Proteome Res 2011;10:1126-38.

68. Gemmell RS. Pregnancy specific B1-glycoprotein in normal and complicated pregnancies. Med Lab Sci 1982;39:245-56.

69. Handwerger $S$, Freemark M. The roles of placental growth hormone and placental lactogen in the regulation of human fetal growth and development. J Pediatr Endocrinol Metab 2000; 13:343-56.

70. Mueller MD, Raio L, Spoerri S, Ghezzi F, Dreher E, Bersinger NA. Novel placental and nonplacental serum markers in ectopic versus normal intrauterine pregnancy. Fertil Steril 2004;81:1106-11.

71. Christiansen M, Sorensen TL, Norgaard-Pedersen B. Human placental lactogen is a first-trimester maternal serum marker of Down syndrome. Prenat Diagn 2007;27:1-5.

72. Rausch ME, Barnhart KT. Serum biomarkers for detecting ectopic pregnancy. Clin Obstet Gynecol 2012;55:418-23.

73. Seeber BE. What serial hCG can tell you, and cannot tell you, about an early pregnancy. Fertil Steril 2012;98:1074-7.

74. Cole LA, Butler SA. Hyperglycosylated human chorionic gonadotropin and human chorionic gonadotropin free beta-subunit: tu- mor markers and tumor promoters. J Reprod Med 2008;53:499512.

75. Sisinni L, Landriscina M. The role of human chorionic gonadotropin as tumor marker: biochemical and clinical aspects. Adv Exp Med Biol 2015;867:159-76.

76. Kharfi A, Giguere Y, De Grandpre P, Moutquin JM, Forest JC. Human chorionic gonadotropin (hCG) may be a marker of systemic oxidative stress in normotensive and preeclamptic term pregnancies. Clin Biochem 2005;38:717-21.

77. Munnangi S, Gross SJ, Madankumar R, Salcedo G, Reznik SE. Pregnancy associated plasma protein-A2: a novel biomarker for Down syndrome. Placenta 2014;35:900-6.

78. Aitken DA, Wallace EM, Crossley JA, Swanston IA, van Pareren Y, van Maarle $M$, et al. Dimeric inhibin A as a marker for Down's syndrome in early pregnancy. $N$ Engl J Med 1996;334:1231-6.

79. Kalousova M, Muravska A, Zima T. Pregnancy-associated plasma protein A (PAPP-A) and preeclampsia. Adv Clin Chem 2014; 63:169-209.

80. De Mees C, Bakker J, Szpirer J, Szpirer C. Alpha-fetoprotein: from a diagnostic biomarker to a key role in female fertility. Biomark Insights 2007;1:82-5.

81. Newby D, Dalgliesh G, Lyall F, Aitken DA. Alphafetoprotein and alphafetoprotein receptor expression in the normal human placenta at term. Placenta 2005;26:190-200.

82. Wald NJ, Huttly WJ, Hackshaw AK. Antenatal screening for Down's syndrome with the quadruple test. Lancet 2003;361:835-6.

83. Leighton PC, Kitau MJ, Chard T, Gordon YB, Leek AE. Levels of alpha-fetoprotein in maternal blood as a screening test for fetal neural-tube defect. Lancet 1975;2:1012-5.

84. Cuckle HS, Wald NJ, Lindenbaum RH. Maternal serum alpha-fetoprotein measurement: a screening test for Down syndrome. Lancet 1984;1:926-9.

85. Kamarainen M, Riittinen L, Seppala M, Palotie A, Andersson LC. Progesterone-associated endometrial protein: a constitutive marker of human erythroid precursors. Blood 1994;84:467-73.

86. Wang P, Zhu L, Zhang X. The role of placental protein 14 in the pathogenesis of endometriosis. Reprod Sci 2013;20:1465-70.

87. Bersinger NA, Birkhauser MH, Yared M, Wunder DM. Serum glycodelin pattern during the menstrual cycle in healthy young women. Acta Obstet Gynecol Scand 2009;88:1215-21.

88. Wei Q, St Clair JB, Fu T, Stratton P, Nieman LK. Reduced expression of biomarkers associated with the implantation window in women with endometriosis. Fertil Steril 2009;91:1686-91.

89. Lass A, Weiser W, Munafo A, Loumaye E. Leukemia inhibitory factor in human reproduction. Fertil Steril 2001;76:1091-6.

90. Senturk LM, Arici A. Leukemia inhibitory factor in human reproduction. Am J Reprod Immunol 1998;39:144-51. 
91. Chen F, Ren P, Feng Y, Liu H, Sun Y, Liu Z, et al. Follistatin is a novel biomarker for lung adenocarcinoma in humans. PLoS One 2014;9:e111398.

92. Daponte A, Deligeoroglou E, Garas A, Pournaras S, Hadjichristodoulou C, Messinis IE. Activin A and follistatin as biomarkers for ectopic pregnancy and missed abortion. Dis Markers 2013;35: 497-503.

93. Ramos IM, Podgaec S, Abrao MS, Oliveira Rd, Baracat EC. Evaluation of CA-125 and soluble CD-23 in patients with pelvic endometriosis: a case-control study. Rev Assoc Med Bras (1992) 2012;58:26-32.

94. Feeley KM, Wells M. Precursor lesions of ovarian epithelial malignancy. Histopathology 2001;38:87-95.

95. Bairey O, Blickstein D, Stark P, Prokocimer M, Nativ HM, Kirgner I, et al. Serum CA 125 as a prognostic factor in non-Hodgkin's lymphoma. Leuk Lymphoma 2003;44:1733-8.

96. Hedman M, Arnberg H, Wernlund J, Riska H, Brodin O. Tissue polypeptide antigen (TPA), hyaluronan and CA 125 as serum markers in malignant mesothelioma. Anticancer Res 2003;23: 531-6.

97. Whiteley MS, Marshall J. Raised serum CA125 level in leiomyoma and leiomyosarcoma of gastrointestinal origin. Br J Surg 1993;80:1551.

98. Berruti A, Tampellini M, Torta M, Buniva T, Gorzegno G, Dogliotti L. Prognostic value in predicting overall survival of two mucinous markers: CA 15-3 and CA 125 in breast cancer patients at first relapse of disease. Eur J Cancer 1994;30:2082-4.

99. Yamamoto M, Baba H, Toh Y, Okamura T, Maehara Y. Peritoneal lavage CEA/CA125 is a prognostic factor for gastric cancer patients. J Cancer Res Clin Oncol 2007;133:471-6.

100. Bon GG, Kenemans P, Dekker JJ, Hompes PG, Verstraeten RA, van Kamp GJ, et al. Fluctuations in CA 125 and CA 15-3 serum concentrations during spontaneous ovulatory cycles. Hum Reprod 1999;14:566-70.

101. Kalambokis G, Kostoula A, Economou M, Tsianos EV. Tumor necrosis factor-alpha-related intraperitoneal release of CA 125 in cirrhotic patients with sterile ascites. Clin Chem 2005;51:2207-8.

102. Kouris NT, Zacharos ID, Kontogianni DD, Goranitou GS, Sifaki MD, Grassos $\mathrm{HE}$, et al. The significance of CA125 levels in patients with chronic congestive heart failure: correlation with clinical and echocardiographic parameters. Eur J Heart Fail 2005;7:199-203.

103. Bilgin T, Karabay A, Dolar E, Develioglu OH. Peritoneal tuberculosis with pelvic abdominal mass, ascites and elevated CA 125 mimicking advanced ovarian carcinoma: a series of 10 cases. Int J Gynecol Cancer 2001;11:290-4.

104. Lotti F, Maggi M. Interleukin 8 and the male genital tract. J Reprod Immunol 2013;100:54-65.
105. Shahzad A, Knapp M, Lang I, Kohler G. Interleukin 8 (IL-8): a universal biomarker? Int Arch Med 2010;3:11.

106. Chutia H. Interleukin-6 (IL-6) as an alternative biomarker of carcinoma prostate. Int J Health Sci Res 2013;3:19-22.

107. Tortorella C, Piazzolla G, Matteo M, Pinto V, Tinelli R, Sabba C, et al. Interleukin-6, interleukin-1 $\beta$, and tumor necrosis factor $\alpha$ in menstrual effluents as biomarkers of chronic endometritis. Fertil Steril 2014;101:242-7.

108. Wieser F, Fabjani G, Tempfer C, Schneeberger C, Zeillinger R, Huber JC, et al. Tumor necrosis factor-alpha promotor polymorphisms and endometriosis. J Soc Gynecol Investig 2002;9:3138.

109. Sikka SC, Wang R. Endocrine disruptors and estrogenic effects on male reproductive axis. Asian J Androl 2008;10:134-45.

110. Heikaus S, Winterhager E, Traub O, Grummer R. Responsiveness of endometrial genes Connexin26, Connexin43, C3 and clusterin to primary estrogen, selective estrogen receptor modulators, phyto- and xenoestrogens. J Mol Endocrinol 2002;29:239-49.

111. Diel P, Schulz T, Smolnikar K, Strunck E, Vollmer G, Michna H. Ability of xeno- and phytoestrogens to modulate expression of estrogen-sensitive genes in rat uterus: estrogenicity profiles and uterotropic activity. J Steroid Biochem Mol Biol 2000;73:1-10.

112. Hopert AC, Beyer A, Frank K, Strunck E, Wunsche W, Vollmer G. Characterization of estrogenicity of phytoestrogens in an endometrial-derived experimental model. Environ Health Perspect 1998;106:581-6.

113. Cheek AO, Brouwer TH, Carroll S, Manning S, McLachlan JA, Brouwer M. Experimental evaluation of vitellogenin as a predictive biomarker for reproductive disruption. Environ Health Perspect 2001;109:681-90.

114. Tian H, Ru S, Wang Z, Cai W, Wang W. Estrogenic effects of monocrotophos evaluated by vitellogenin mRNA and protein induction in male goldfish (Carassius auratus). Comp Biochem Physiol C Toxicol Pharmacol 2009;150:231-6.

115. Henry TB, McPherson JT, Rogers ED, Heah TP, Hawkins SA, Layton $A C$, et al. Changes in the relative expression pattern of multiple vitellogenin genes in adult male and larval zebrafish exposed to exogenous estrogens. Comp Biochem Physiol A Mol Integr Physiol 2009;154:119-26.

116. Jung EM, An BS, Yang H, Choi KC, Jeung EB. Biomarker genes for detecting estrogenic activity of endocrine disruptors via estrogen receptors. Int J Environ Res Public Health 2012;9:698-711.

117. Jakowlew SB, Breathnach R, Jeltsch JM, Masiakowski P, Chambon $P$. Sequence of the pS2 mRNA induced by estrogen in the human breast cancer cell line MCF-7. Nucleic Acids Res 1984;12:2861-78.

118. Zajchowski DA, Sager R. Induction of estrogen-regulated genes differs in immortal and tumorigenic human mammary epithe- 
lial cells expressing a recombinant estrogen receptor. Mol Endocrinol 1991;5:1613-23.

119. Vivacqua A, Recchia AG, Fasanella G, Gabriele S, Carpino A, Rago $V$, et al. The food contaminants bisphenol A and 4-nonylphenol act as agonists for estrogen receptor alpha in MCF7 breast cancer cells. Endocrine 2003;22:275-84.

120. Ren L, Marquardt MA, Lech JJ. Estrogenic effects of nonylphenol on PS2, ER and MUC1 gene expression in human breast cancer cells-MCF-7. Chem Biol Interact 1997;104:55-64.

121. Bagchi IC, Cheon YP, Li Q, Bagchi MK. Progesterone receptor-regulated gene networks in implantation. Front Biosci 2003;8:585261.
122. Beyer C, Damm N, Brito V, Kuppers E. Developmental expression of progesterone receptor isoforms in the mouse midbrain. Neuroreport 2002;13:877-80.

123. Sauter CN, McDermid RL, Weinberg AL, Greco TL, Xu X, Murdoch $\mathrm{FE}$, et al. Differentiation of murine embryonic stem cells induces progesterone receptor gene expression. Exp Cell Res 2005;311: 251-64.

124. An BS, Choi KC, Kang SK, Hwang WS, Jeung EB. Novel calbindin$D(9 k)$ protein as a useful biomarker for environmental estrogenic compounds in the uterus of immature rats. Reprod Toxicol 2003;17:311-9. 